\title{
THE EFFECTS OF VARIOUS ROW SPACING AND SOWING PERIODS ON THE PLANT PROPERTIES OF QUINOA (Chenopodium quinoa Willd.)
}

\author{
ZULKADIR, G. \\ Mersin University, Applied Technology and Management School of Silifke, Organic Farming \\ Management Department, Silifke, Mersin/Turkey \\ (e-mail: gulayzulkadir@gmail.com; phone: +90-507-995-2958) \\ (Received $9^{\text {th }}$ Dec 2020; accepted $3^{\text {rd }}$ Mar 2021)
}

\begin{abstract}
Quinoa is a highly nutritional plant that could adapt to different growth conditions. Thus, it is cultivated and consumed globally. However, to grow quinoa outside its indigenous geography, factors such as the sowing period and row spacing should be determined in advance to maximize yield. Thus, the present study aimed to determine the differences that could be observed throughout the total growth period of quinoa with different sowing periods and row spacing applications under Mediterranean climatic conditions. The study findings demonstrated that the plant branch count varied between 1.3 and 20.2, the plant height varied between 30.9 and $104.0 \mathrm{~cm}$, the main panicle length varied between 15.0 and $41.2 \mathrm{~cm}$, the plant weight varied between 0.01 and $52.2 \mathrm{~g}$, the plant yield in parcel varied between 71.2 and $3199.1 \mathrm{~g}$ and the harvest index varied between 5.1 and $52.5 \%$. According to the results quinoa should be sowed in the first or second half of April in the region based on the climate, and the ideal row spacing should be $40 \mathrm{~cm}$. The analysis revealed that this row spacing leads to maximum yield, while sowing period could vary due to the impact of climatic factors.
\end{abstract}

Keywords: ecologycal impact, harvest index, panicle length, plant height, plant yield

\section{Introduction}

Quinoa (Chenopodium quinoa Willd.) is a plant that has been known for a long time cultivated in the Andean region for centuries to consume the seeds and leaves (Jacobsen, 2017). However, the cultivation and consumption of quinoa became popular globally during the last three decades (Wu et al., 2017). Today, it is cultivated in more than 90 countries, $80 \%$ of the cultivation is in Bolivia and Peru, while the remaining $20 \%$ is distributed among several countries (Bazile et al., 2016).

The popularity of quinoa is due to its high nutritional content, adaptability and ability to grow in harsh climatic conditions, making it an ideal crop for drought-prone and saline agricultural lands (Bazile et al., 2016). Due to its outstanding nutritional properties, the global quinoa market is currently increasing rapidly (Jacobsen, 2017). In addition to its high protein content, the plant is rich in nutrients including balanced amino acids and high mineral concentrations. Studies demonstrated that only a limited number of grain seeds do not contain gluten and the quality of the mineral, vitamin, antioxidant and protein content is comparable to casein. It was also evidenced to have high levels of essential amino acids such as lysine (Wu et al., 2016).

Another factor in the prevalence of quinoa cultivation is its adaptation to various ecological conditions. In other words, quinoa could survive $4000 \mathrm{~m}$ above the sea level and in temperatures between -8 and $38{ }^{\circ} \mathrm{C}$. However, despite its wide ecological range, significant yield differences are observed based on the variety, and soil, water and climate conditions (Scanlin and Lewis, 2017). For instance, high temperatures during flowering and grain filling periods significantly reduces yield (Hinojosa et al., 2018). In fact, during the flowering period, night temperatures between 20 and $22{ }^{\circ} \mathrm{C}$ reduces grain yield by 
$23 \%$ to $31 \%$ (Lesjak and Calderini, 2017). On the other hand, the impact of heat stress, duration, intensity and the rate of temperature increase is a complex function (Wahid et al., 2007), and heat stress leads to different reactions among plant species based on the duration of temperature increase and the plant development period in which heat stress occurs. In general, the plant flowering stage is more susceptible to heat stress when compared to the vegetative stages (Prasad et al., 2017).

Perhaps the most important agricultural application that affect crop yield is the sowing density. In each cultivation system, there is a plant density that would maximize the consumption of available resources (such as water, nutrients and daylight) and allows the achievement of the maximum yield (Sangoi et al., 2000).

Based on the above-mentioned information, determination of the most adequate sowing period and sowing density would balance the plant requirements and environmental conditions to maximize the yield and quality in quinoa cultivation. Due to these requirements, the present study aimed to determine the possible variations based on different sowing periods and row spacing within the overall quinoa plant growth period and identify certain properties of the quinoa plant in Mediterranean climate conditions.

\section{Materials and Methods}

The present study was conducted for two years in Kahramanmaras province ecological conditions during 2016 and 2017 in Turkey. In the experiments, "Q52" quinoa variety, compatible with the Mediterranean climate conditions, was employed. The study area soil analysis results are presented in Table 1 and climate data are presented in Table 2.

Table 1. Some soil characteristics of experimental areas in the 2017-2018

\begin{tabular}{|c|c|c|c|c|c|c|c|c|}
\hline \multicolumn{2}{|c|}{$\begin{array}{c}\text { Soil } \\
\text { properties }\end{array}$} & $\begin{array}{c}\text { Saturation } \\
(\%)\end{array}$ & pH & EC dS m ${ }^{-1}$ & $\begin{array}{c}\text { Lime } \\
(\%) \\
\end{array}$ & \begin{tabular}{|c|} 
Organic Matter \\
$(\%)$
\end{tabular} & $\begin{array}{c}\mathrm{P}_{2} \mathrm{O}_{5} \\
\left(\mathrm{~kg} \mathrm{da}^{-1}\right) \\
\end{array}$ & $\begin{array}{c}\mathrm{K}_{2} \mathrm{O} \\
\left(\mathrm{kg} \mathrm{da}^{-1}\right)\end{array}$ \\
\hline \multirow[b]{2}{*}{2017} & Values & 58.00 & 7.76 & 0.32 & 24.48 & 2.28 & 3.20 & 98.64 \\
\hline & Comments & $\begin{array}{l}\text { Clay- } \\
\text { Loamy }\end{array}$ & $\begin{array}{l}\text { Light } \\
\text { Alkaline }\end{array}$ & $\begin{array}{l}\text { Light } \\
\text { Saline }\end{array}$ & More Lime & Middle & Low & High \\
\hline \multirow{2}{*}{2018} & Values & 79.00 & 7.40 & 0.11 & 23.00 & 2.09 & 5.62 & 61.2 \\
\hline & Comments & Clay & Neutral & Saltless & Limy & Middle & Poor & High \\
\hline
\end{tabular}

As seen in Table 1, the test site soil content was low in phosphorus content, adequate in potassium, and moderate in organic matter content for both years of experiment. However, based on the year and location, soil saturation changed from clayey-loamy to clayey, and it was determined that the soil was slightly alkaline-neutral, slightly saltysalt-free, highly calcareous-calcareous.

It was observed that the total historical precipitation was $135.5 \mathrm{~mm}$ and the mean precipitation in the season that the experiment was conducted was $22.6 \mathrm{~mm}$ as seen in Table 2. During the experiments, total and average precipitation figures were 176.2 and $29.4 \mathrm{~mm}$ for the first year, 140.0 and $23.3 \mathrm{~mm}$ for the second year. It was determined that the average precipitation in both years was higher than the historical average precipitation. The seasonal average temperatures in the region were $21.7^{\circ} \mathrm{C}$ and $11.5^{\circ} \mathrm{C}$, respectively. In the study, the mean temperature was $23.2^{\circ} \mathrm{C}$ in the 2017 cultivation period, and the mean temperature was $23.5^{\circ} \mathrm{C}$ in the 2018 cultivation period, and both figures were higher than the historical average. 


$$
-1859 \text { - }
$$

Table 2. Some meteorological parameters of experimental areas at Kahramanmaras in 2017 and 2018 and irrigation dates

\begin{tabular}{|c|c|c|c|c|c|c|c|c|c|c|c|c|c|c|c|}
\hline \multirow{2}{*}{ Months } & \multicolumn{3}{|c|}{ Max. Temperature $\left({ }^{\circ} \mathrm{C}\right)$} & \multicolumn{3}{|c|}{ Min. Temperature $\left({ }^{\circ} \mathrm{C}\right)$} & \multicolumn{3}{|c|}{ Average temperature $\left({ }^{\circ} \mathrm{C}\right)$} & \multicolumn{3}{|c|}{ Total rainfall $(\mathrm{mm})$} & \multicolumn{3}{|c|}{ Average relative humidity $(\%)$} \\
\hline & 2017 & 2018 & 1963-2018 & 2017 & 2018 & 1963-2018 & 2017 & 2018 & $1963-2018$ & 2017 & 2018 & $1963-2018$ & 2017 & 2018 & $1963-2018$ \\
\hline March & 17.9 & 19.7 & 15.9 & 7.2 & 9.6 & 5.8 & 12.2 & 14.2 & 10.4 & 74.2 & 47.4 & 97.5 & 55.1 & 60.8 & 60.4 \\
\hline April & 21.8 & 25.5 & 21.3 & 10.1 & 12 & 9.9 & 15.7 & 18.4 & 15.2 & 68.1 & 71.6 & 72.7 & 49.7 & 45.3 & 57.5 \\
\hline May & 26.2 & 28.8 & 26.7 & 14.2 & 15.7 & 14.2 & 19.6 & 21.7 & 20.0 & 105.0 & 28.1 & 40.0 & 54.9 & 52.6 & 54.6 \\
\hline June & 33.3 & 32.5 & 32.0 & 19.9 & 19.9 & 18.9 & 26.2 & 25.4 & 24.9 & 3.1 & 39.4 & 7.8 & 43.3 & 49.1 & 48.8 \\
\hline July & 39.1 & 35.6 & 35.7 & 23.9 & 23.2 & 22.2 & 30.9 & 28.6 & 28.3 & 0.0 & 0.3 & 2.7 & 34.9 & 46.2 & 49.9 \\
\hline August & 37.9 & 36.8 & 36.1 & 23.7 & 23.3 & 22.2 & 29.8 & 29.1 & 28.4 & 0.0 & 0.0 & 2.3 & 46.2 & 43.8 & 51.2 \\
\hline September & 36.4 & 34.7 & 32.6 & 21.1 & 21.0 & 18.5 & 27.7 & 27.2 & 24.9 & 0.0 & 0.6 & 10.0 & 38.3 & 38.4 & 48.8 \\
\hline Total (Season) & 212.6 & 213.6 & 200.3 & 120.1 & 124.7 & 111.7 & 162.1 & 164.6 & 152.1 & 176.2 & 140.0 & 135.5 & 322.4 & 336.2 & 371.2 \\
\hline Average (Season) & 30.4 & 30.5 & 28.6 & 17.2 & 17.8 & 16.0 & 23.2 & 23.5 & 21.7 & 29.4 & 23.3 & 22.6 & 46.1 & 48.0 & 53.0 \\
\hline
\end{tabular}

\begin{tabular}{|c|c|c|c|c|c|c|c|c|c|}
\hline Irrigations & & & & & & & & & \\
\hline 2017 & March 24 & April 20 & April 28 & May 11 & June 09 & June 21 & July 01 & July 10 & July 25 \\
\hline 2018 & March 26 & April 17 & April 28 & May 13 & June 08 & June 21 & June 28 & July 21 & August 09 \\
\hline
\end{tabular}


The mean relative humidity in Kahramanmaras was $53.0 \%$ in the season, $58.1 \%$ throughout the year, while it was $46.1 \%$ and $48.0 \%$, respectively in the 2017 and 2018 cultivation seasons (Anonymous, 2019).

The experiment was set up with random plots with different sowing times (ST) (March 23, April 6, 20, May 11 in 2017; March 26, April 2, 13, and 26 in 2018), and different row spacing $(\mathrm{RS})(20,40$ and $60 \mathrm{~cm})$ in sub-plots and 3 repetitions. The plants were sowed with $20 \mathrm{~cm}, 40 \mathrm{~cm}$ and $60 \mathrm{~cm}$ (4 rows per lot) row spacing on the lines marked with a hand marker and at 1-2 cm depth. The size of the plots was $4 \mathrm{~m}^{2}, 8 \mathrm{~m}^{2}$ and $12 \mathrm{~m}^{2}$. The TKW value of the seed material used was $2.15 \mathrm{~g}$, and the amount of seed sown in the experimental plots was $1.2 \mathrm{~kg} \mathrm{da}^{-1}$. Based on the soil nutrient content (Table 1), presowing fertilization was conducted with $0.6 \mathrm{~kg} \mathrm{ha}^{-1} \mathrm{~N}, 0.6 \mathrm{~kg} \mathrm{ha}^{-1} \mathrm{P}$ and $0.6 \mathrm{~kg} \mathrm{ha}^{-1} \mathrm{~K}$. After sowing, when plants were about $20 \mathrm{~cm}$ high, net $0.7 \mathrm{~kg} \mathrm{ha}^{-1} \mathrm{~N}$ was applied in the second fertilization. Based on the climate conditions, the plots were irrigated based on the water requirement of the quinoa plant (Table 2). Weed control was conducted manually based on the weed prevalence in the field.

The observations in the research were determined as the number of brances in the plant (NBP), the plant height (PH), the main panicle length (MPL), plant weight (PW), the plant yield per parcel (PY) and harvest index (HI) (Kir and Temel, 2017). The data obtained from the research were analyzed through variance analysis by means of SAS (version 6.03) program, and Duncan multiple comparison test was implemented to determine the significance levels of the differences among the implementations.

\section{Results and Discussion}

The results of the analysis of variance conducted on the data obtained with various sowing time and row spacing applications during the two years of experiment and the comparison of the data averages are presented in Table 3 (Tables 3.1, 3.2, 3.3).

Table 3.1. Means and $F$ values of different years, sowing dates and row spacings on the phenological characteristics of quinoa in 2017 and 2018

\begin{tabular}{c|c|c|c|c|c|c}
\hline & NBP & PH & MPL & PW & PY & HI \\
\hline Year & & & & & & \\
2017 & $4.173 \mathrm{~B}$ & $77.628 \mathrm{~B}$ & $24.410 \mathrm{~B}$ & $14.331 \mathrm{~B}$ & $1378.05 \mathrm{~B}$ & $31.703 \mathrm{~A}$ \\
2018 & $15.653 \mathrm{~A}$ & $84.162 \mathrm{~A}$ & $28.150 \mathrm{~A}$ & $25.448 \mathrm{~A}$ & $2271.21 \mathrm{~A}$ & $24.875 \mathrm{~B}$ \\
F values & $\mathbf{4 1 4 6 . 5 2 * *}$ & $\mathbf{2 7 . 7 6 * *}$ & $\mathbf{9 6 . 5 3} *$ & $\mathbf{1 1 8 6 . 0 7} * *$ & $\mathbf{8 9 3 . 5 5 * *}$ & $\mathbf{2 9 5 . 2 6} * *$ \\
\hline Sowing Time & & & & & & \\
$23 / 26$ March (I) & $8.139 \mathrm{C}$ & $89.636 \mathrm{~A}$ & $33.228 \mathrm{~A}$ & $32.109 \mathrm{~A}$ & $2067.26 \mathrm{~A}$ & $28.876 \mathrm{~B}$ \\
$06 / 02$ April (II) & $8.504 \mathrm{C}$ & $81.122 \mathrm{~B}$ & $22.444 \mathrm{C}$ & $21.779 \mathrm{C}$ & $1826.71 \mathrm{~B}$ & $31.326 \mathrm{~A}$ \\
20/13 April (III) & $10.241 \mathrm{~B}$ & $87.822 \mathrm{~A}$ & $23.336 \mathrm{C}$ & $24.366 \mathrm{~B}$ & $1884.32 \mathrm{~B}$ & $29.202 \mathrm{~B}$ \\
04 May/26 April (IV) & $12.767 \mathrm{~A}$ & $65.000 \mathrm{C}$ & $26.111 \mathrm{~B}$ & $1.302 \mathrm{D}$ & $1520.23 \mathrm{C}$ & $23.752 \mathrm{C}$ \\
F values & $\mathbf{1 4 0 . 3 6 * *}$ & $\mathbf{8 1 . 7 1 * *}$ & $\mathbf{1 6 4 . 8 6} * *$ & $\mathbf{1 6 5 8 . 6 2} * *$ & $\mathbf{5 7 . 9 1} * *$ & $\mathbf{6 5 . 4 0} * *$ \\
\hline Row Spacing & & & & & & \\
$20 \mathrm{~cm}$ & $9.489 \mathrm{~B}$ & $76.846 \mathrm{~B}$ & $25.202 \mathrm{C}$ & $16.844 \mathrm{C}$ & $1636.39 \mathrm{C}$ & $30.891 \mathrm{~A}$ \\
$40 \mathrm{~cm}$ & $10.183 \mathrm{~A}$ & $82.944 \mathrm{~A}$ & $27.408 \mathrm{~A}$ & $22.152 \mathrm{~A}$ & $2048.02 \mathrm{~A}$ & $30.821 \mathrm{~A}$ \\
$60 \mathrm{~cm}$ & $10.067 \mathrm{~A}$ & $82.896 \mathrm{~A}$ & $26.229 \mathrm{~B}$ & $20.673 \mathrm{~B}$ & $1789.49 \mathrm{~B}$ & $23.155 \mathrm{~B}$ \\
F values & $\mathbf{4 . 6 0 *}$ & $\mathbf{1 1 . 6 6 * *}$ & $\mathbf{1 0 . 4 7 * *}$ & $\mathbf{6 7 . 1 8} * *$ & $\mathbf{8 0 . 7 2} * *$ & $\mathbf{3 0 2 . 2 0} * *$ \\
\hline
\end{tabular}

$*: \mathrm{p}<0.05, * *: \mathrm{p}<0.01$, IS: insignificant, NBP: the number of brances in the plant, PH: the plant height, MPL: the main panicle length, PW: single plant weight, PY: the plant yield per parcel, HI: harvest index 
Table 3.2. Means and $F$ values of year $x$ sowing time, year $x$ row spacing and sowing time $x$ row spacing interactions on the phenological characteristics of quinoa in 2017 and 2018

\begin{tabular}{|c|c|c|c|c|c|c|c|}
\hline \multicolumn{8}{|c|}{ Year X Sowing Time } \\
\hline \multirow{4}{*}{2017} & I & 2.533 & 95.689 & 39.211 & 21.387 & 1803.387 & 27.851 \\
\hline & II & 3.587 & 87.311 & 19.978 & 16.257 & 1579.199 & 34.241 \\
\hline & III & 4.594 & 93.222 & 20.139 & 17.090 & 1870.377 & 27.163 \\
\hline & IV & 5.978 & 34.289 & 18.311 & 2.591 & 259.256 & 37.558 \\
\hline \multirow{4}{*}{2018} & $\mathrm{I}$ & 13.744 & 83.583 & 27.244 & 42.832 & 2331.136 & 29.900 \\
\hline & II & 13.422 & 74.933 & 24.911 & 27.302 & 2074.228 & 28.411 \\
\hline & III & 15.889 & 82.422 & 26.533 & 31.642 & 1898.271 & 31.241 \\
\hline & IV & 19.556 & 95.711 & 33.911 & 0.013 & 2781.207 & 9.947 \\
\hline \multicolumn{2}{|c|}{ F values } & $18.91 * *$ & $217.66 * *$ & $227.60 * *$ & $244.77 * *$ & $344.78 * *$ & $332.78 * *$ \\
\hline \multicolumn{8}{|c|}{ Year X Row Spacing } \\
\hline \multirow{3}{*}{2017} & $20 \mathrm{~cm}$ & 3.944 & 72.042 & 24.404 & 12.198 & 1281.360 & 35.305 \\
\hline & $40 \mathrm{~cm}$ & 4.858 & 82.567 & 25.633 & 15.010 & 1772.133 & 36.277 \\
\hline & $60 \mathrm{~cm}$ & 3.717 & 78.275 & 23.192 & 15.785 & 1080.670 & 23.528 \\
\hline \multirow{3}{*}{2018} & $20 \mathrm{~cm}$ & 15.033 & 81.650 & 26.000 & 21.489 & 1991.417 & 26.477 \\
\hline & $40 \mathrm{~cm}$ & 15.508 & 83.321 & 29.183 & 29.293 & 2323.908 & 25.365 \\
\hline & $60 \mathrm{~cm}$ & 16.417 & 87.517 & 29.267 & 25.560 & 2498.307 & 22.783 \\
\hline \multicolumn{2}{|c|}{ F values } & $9.68 * *$ & $5.95 * *$ & $10.83 * *$ & $16.97 * *$ & $99.11 * *$ & $110.21 * *$ \\
\hline \multicolumn{8}{|c|}{ Sowing Time X Row Spacing } \\
\hline \multirow{3}{*}{ I } & $20 \mathrm{~cm}$ & 7.500 & 83.367 & 32.383 & 24.823 & 1454.722 & 27.170 \\
\hline & $40 \mathrm{~cm}$ & 8.167 & 94.008 & 35.167 & 36.618 & 2615.743 & 33.065 \\
\hline & $60 \mathrm{~cm}$ & 8.750 & 91.533 & 32.133 & 34.887 & 2131.318 & 26.392 \\
\hline \multirow{3}{*}{ II } & $20 \mathrm{~cm}$ & 8.113 & 75.333 & 20.467 & 20.647 & 1792.382 & 36.810 \\
\hline & $40 \mathrm{~cm}$ & 8.783 & 80.467 & 21.333 & 24.073 & 2093.707 & 30.745 \\
\hline & $60 \mathrm{~cm}$ & 8.617 & 87.567 & 25.533 & 20.618 & 1594.052 & 26.423 \\
\hline \multirow{3}{*}{ III } & $20 \mathrm{~cm}$ & 9.608 & 84.033 & 20.925 & 20.560 & 1579.998 & 30.602 \\
\hline & $40 \mathrm{~cm}$ & 10.550 & 92.367 & 26.600 & 26.162 & 1961.240 & 27.925 \\
\hline & $60 \mathrm{~cm}$ & 10.567 & 87.067 & 22.483 & 26.377 & 2111.733 & 29.080 \\
\hline \multirow{3}{*}{ IV } & $20 \mathrm{~cm}$ & 12.733 & 64.650 & 27.033 & 1.345 & 1718.452 & 28.982 \\
\hline & $40 \mathrm{~cm}$ & 13.233 & 64.933 & 26.533 & 1.753 & 1521.392 & 31.548 \\
\hline & $60 \mathrm{~cm}$ & 12.333 & 65.417 & 24.767 & 0.808 & 1320.850 & 10.727 \\
\hline \multicolumn{2}{|c|}{ F values } & 1.28 IS & $2.96^{*}$ & $10.96 * *$ & $19.10 * *$ & $\mathbf{5 3 . 5 9} * *$ & $117.43^{* *}$ \\
\hline
\end{tabular}

$*: \mathrm{p}<0.05, * *: \mathrm{p}<0.01$, IS: insignificant, NBP: the number of brances in the plant, PH: the plant height, MPL: the main panicle length, PW: single plant weight, PY: the plant yield per parcel, HI: harvest index

\section{The number of branches per plant}

Based on the study findings, there were statistically significant differences between $Y$, ST, Y x ST, Y x RS, Y x ST x RS factors $(\mathrm{p}<0.01)$ and RS $(\mathrm{p}<0.05)$ based on NBP property, while ST x RS interaction was insignificant. NBP was higher in 2018 (15.7) when compared to 2017 (4.2). The analysis of the applications based on ST demonstrated that the highest figure was obtained in the $4^{\text {th }}$ sowing (12.8), and the lowest figures were obtained in the $1^{\text {st }}$ and $2^{\text {nd }}$ sowing. The analysis of RS application demonstrated that the lowest value was obtained with $20 \mathrm{~cm}$ row spacing and the other two RS applications yielded statistically the same figures. 
Table 3.3. Means and $F$ values of year $x$ sowing time $x$ row spacing on the phenological characteristics of quinoa in 2017 and 2018

\begin{tabular}{|c|c|c|c|c|c|c|c|}
\hline \multicolumn{8}{|c|}{ Year X Sowing Time X Row Spacing } \\
\hline \multirow{4}{*}{ I } & $20 \mathrm{~cm}$ & 1.267 & 87.533 & 41.233 & 16.540 & 1151.840 & 25.373 \\
\hline & $40 \mathrm{~cm}$ & 3.767 & 103.133 & 39.800 & 21.080 & 2704.600 & 35.003 \\
\hline & $60 \mathrm{~cm}$ & 2.567 & 96.400 & 36.600 & 26.540 & 1553.720 & 23.177 \\
\hline & $20 \mathrm{~cm}$ & 4.360 & 80.200 & 19.000 & 14.287 & 2029.697 & 45.370 \\
\hline II & $40 \mathrm{~cm}$ & 3.033 & 86.133 & 17.667 & 16.107 & 1801.383 & 32.067 \\
\hline \multirow{2}{*}{2017} & $60 \mathrm{~cm}$ & 3.367 & 95.600 & 23.267 & 18.377 & 906.527 & 25.287 \\
\hline & $20 \mathrm{~cm}$ & 4.083 & 85.467 & 17.050 & 15.287 & 1706.073 & 26.667 \\
\hline \multirow[t]{3}{*}{ III } & $40 \mathrm{~cm}$ & 5.233 & 104.000 & 25.467 & 19.357 & 2113.863 & 25.503 \\
\hline & $60 \mathrm{~cm}$ & 4.467 & 90.200 & 17.900 & 16.627 & 1791.193 & 29.320 \\
\hline & $20 \mathrm{~cm}$ & 6.067 & 34.967 & 20.333 & 2.680 & 237.830 & 43.810 \\
\hline \multirow[t]{3}{*}{ IV } & $40 \mathrm{~cm}$ & 7.400 & 37.000 & 19.600 & 3.497 & 468.697 & 52.533 \\
\hline & $60 \mathrm{~cm}$ & 4.467 & 30.900 & 15.000 & 1.597 & 71.240 & 16.330 \\
\hline & $20 \mathrm{~cm}$ & 13.733 & 79.200 & 23.533 & 33.107 & 1757.603 & 28.967 \\
\hline \multirow[t]{3}{*}{ I } & $40 \mathrm{~cm}$ & 12.567 & 84.883 & 30.533 & 52.157 & 2526.887 & 31.127 \\
\hline & $60 \mathrm{~cm}$ & 14.933 & 86.667 & 27.667 & 43.233 & 2708.917 & 29.607 \\
\hline & $20 \mathrm{~cm}$ & 11.867 & 70.467 & 21.933 & 27.007 & 1555.067 & 28.250 \\
\hline \multirow[t]{2}{*}{ II } & $40 \mathrm{~cm}$ & 14.533 & 74.800 & 25.000 & 32.040 & 2386.040 & 29.423 \\
\hline & $60 \mathrm{~cm}$ & 13.867 & 79.533 & 27.800 & 22.860 & 2281.577 & 27.560 \\
\hline 2018 & $20 \mathrm{~cm}$ & 15.133 & 82.600 & 24.800 & 25.833 & 1453.923 & 34.537 \\
\hline \multirow[t]{3}{*}{ III } & $40 \mathrm{~cm}$ & 15.867 & 80.733 & 27.733 & 32.967 & 1808.617 & 30.347 \\
\hline & $60 \mathrm{~cm}$ & 16.667 & 83.933 & 27.067 & 36.127 & 2432.273 & 28.840 \\
\hline & $20 \mathrm{~cm}$ & 19.400 & 94.333 & 33.733 & 0.010 & 3199.073 & 14.153 \\
\hline \multirow[t]{2}{*}{ IV } & $40 \mathrm{~cm}$ & 19.067 & 92.867 & 33.467 & 0.010 & 2574.087 & 10.563 \\
\hline & $60 \mathrm{~cm}$ & 20.200 & 99.933 & 34.533 & 0.020 & 2570.460 & 5.123 \\
\hline \multicolumn{2}{|c|}{ F values } & $6.14 * *$ & 2.08 IS & $6.16 * *$ & $17.86 * *$ & $35.98 * *$ & $86.71 * *$ \\
\hline
\end{tabular}

$*: \mathrm{p}<0.05, * *: \mathrm{p}<0.01$, IS: insignificant, NBP: the number of brances in the plant, PH: the plant height, MPL: the main panicle length, PW: single plant weight, PY: the plant yield per parcel, HI: harvest index

In the Y x ST interaction, the lowest value was obtained in the first sowing (2.5) in 2017 and the highest value was obtained in the fourth sowing (19.5) in 2018. In the Y x RS interaction, the lowest value was determined with $60 \mathrm{~cm}$ RS (3.7) in 2017 and the highest was determined with $60 \mathrm{~cm}$ RS (16.4) in 2018. The lowest value in Y x ST x RS interaction was $1.3\left(1^{\text {st }}\right.$ sowing in 2017) and the highest value was $20.2\left(4^{\text {th }}\right.$ sowing in 2018).

Previous studies reported different values on the branching characteristics of the quinoa plant. Thus, Naik et al. (2020) reported 17.70 branches per plant, Onkur and Keskin (2019) reported 19.9-26.4 per plant, Afiah et al. (2018) reported 2.1-4.4 per plant, Al-Naggar et al. (2017) reported 7.0-20.0 per plant, K1r and Temel (2017) reported 15.1-26.0 per plant, Dumanoglu et al. (2016) reported 4.0-8.0 per plant, and Long (2016) reported 4.28-15.75 branches per plant. The wide range in reported values were due to employment of different varieties, ecological, climatic, soil structure differences, row spacing and sowing method. Although the present study data were compatible with these reports, the differences observed in the present study are explained below. 


\section{The plant height $(\mathrm{cm})$}

In the study, it was determined that there were statistical differences between Y, ST, RS, Y x ST, Y x RS, factors ( $\mathrm{p}<0.01)$ and ST x RS ( $\mathrm{p}<0.05)$ based on PH, while Y x ST $\mathrm{x}$ RS interaction was found to be insignificant. PH was taller in $2018(84.2 \mathrm{~cm})$ when compared to $2017(77.6 \mathrm{~cm})$. The analysis of the applications based on ST revealed that the highest values were obtained in first and third sowings $(89.6$ and $87.8 \mathrm{~cm})$, while the lowest value was obtained in the second sowing $(81.1 \mathrm{~cm})$. The analysis of the RS application revealed that the lowest value was obtained with $20 \mathrm{~cm}$ row spacing and the other two RS produced statistically same values.

In Y x ST interaction, the lowest value was obtained in $4^{\text {th }}$ sowing in $2017(34.3 \mathrm{~cm})$ and the highest was obtained in $4^{\text {th }}$ sowing in $2018(95.7 \mathrm{~cm})$. Furthermore, $95.7 \mathrm{~cm} \mathrm{PH}$ obtained in first sowing in 2017 was the second highest value. In the Y x RS interaction, the lowest PH was obtained with $20 \mathrm{~cm}$ RS in $2017(72.0 \mathrm{~cm})$, and the highest was obtained with $60 \mathrm{~cm}$ RS $(87.5 \mathrm{~cm})$ in 2018. The ST x RS interaction data revealed that the lowest value was $94.0 \mathrm{~cm}\left(1^{\text {st }} ; 40 \mathrm{~cm}\right)$ and the highest value was $64.7 \mathrm{~cm}\left(4^{\text {th }} ; 20 \mathrm{~cm}\right)$.

The PH data reported in other studies were $122.3 \mathrm{~cm}$ (Naik et al., 2020), 66.5-116.4 cm (Tan and Temel, 2018), 35.3-71.6 cm (Eltahan et al., 2019), 73.9-90.3 cm (Altuner et al., 2019), 49.3-101.5 cm (Geren and Gure, 2017), 55.4-101.0 cm (Tan and Temel, 2017), 48.5-94.1 cm (Geren, 2015) and 82-118 cm (Hirich et al., 2014), it was stated that the differences were due to varietal and ecological differences and various stress factors.

\section{The main panicle length (cm)}

The analysis of the differences in MPL property based on the applications, it was determined that the Y, ST, RS, Y x ST, YxRS, ST x RS, Y x ST x RS interactions ( $\mathrm{p}<0.01)$ were significant. MPL was higher in $2018(28.2 \mathrm{~cm})$ when compared to 2017 $(24.4 \mathrm{~cm})$. The analysis of the applications based on ST demonstrated that the highest value was obtained in the first sowing $(33.2 \mathrm{~cm})$, and the lowest value was obtained in the second planting $(22.4 \mathrm{~cm})$. The analysis of the RS application findings revealed that the lowest value was obtained with $20 \mathrm{~cm}$ row spacing and the highest value was obtained with $40 \mathrm{~cm}$ row spacing.

The lowest Y x ST interaction was obtained in fourth sowing in $2017(18.3 \mathrm{~cm})$ and the highest was obtained in fourth sowing in $2018(33.9 \mathrm{~cm})$. The lowest Y x RS interaction was obtained with $60 \mathrm{~cm}$ RS in $2017(23.2 \mathrm{~cm})$, and the highest were obtained with $60 \mathrm{~cm}$ RS $(29.3 \mathrm{~cm})$ and $40 \mathrm{~cm}$ RS $(29.2 \mathrm{~cm})$ in 2018 . The lowest ST x RS interaction was $20.5 \mathrm{~cm}\left(1^{\text {st }} ; 20 \mathrm{~cm}\right)$ and the highest was $35.2 \mathrm{~cm}\left(1^{\text {st. }} ; 40 \mathrm{~cm}\right)$. Finally, the lowest Y x ST x RS interaction was $15.0 \mathrm{~cm}\left(2017 ; 4^{\text {th }} ; 60 \mathrm{~cm}\right)$ and the highest was $41.2 \mathrm{~cm}$ $\left(2017 ; 1^{\text {st. }} ; 20 \mathrm{~cm}\right)$.

Previous studies reported variable panicle length figures such as 31.1-42.8 cm (Altuner et al., 2019), 20.0-36.0 cm (Reguera et al., 2018), 17.8-25.3 cm (Rames et al., 2017), 24.3-29.1 cm (Long, 2016), 38.3-53.3 cm (Geren et al., 2015), 28.6-53.3 cm (Geren et al., 2014) and $15-57 \mathrm{~cm}$ (Hirich et al., 2014). The present study data were consistent with other studies.

\section{Plant weight (g plant $\left.{ }^{-1}\right)$}

The analysis of the differences between the applications based on PW of the harvested samples revealed that Y, ST, RS, Y x ST, Y x RS, ST x RS, Y x ST x RS interactions ( $p<0.01)$ were statistically significant. PW was higher in $2018\left(25.4 \mathrm{~g} \mathrm{plant}^{-1}\right)$ when 
compared to 2017 (14.3 $\left.\mathrm{g}_{\text {plant }}{ }^{-1}\right)$. The analysis of the applications based on ST demonstrated that the highest value was obtained in the first sowing ( $\left.32.1 \mathrm{~g} \mathrm{plant}^{-1}\right)$, and the lowest value was obtained in the fourth sowing $\left(1.3 \mathrm{~g} \mathrm{plant}^{-1}\right)$. The analysis of the applications based on RS revealed that the lowest value was $16.8 \mathrm{~cm}$ with $20 \mathrm{~cm}$ RS, while the highest value was $22.2 \mathrm{~g}$ with $40 \mathrm{~cm}$ RS.

The lowest Y x ST interaction was obtained in $4^{\text {th }}$ sowing in $2017\left(2.6 \mathrm{~g} \mathrm{plant}^{-1}\right)$ and the highest was obtained in $1^{\text {st }}$ sowing in 2018 (42.8 $\mathrm{g}$ plant $\left.^{-1}\right)$. The highest $\mathrm{Y} \times \mathrm{RS}$

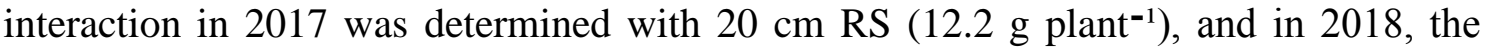
highest value was determined with $40 \mathrm{~cm}$ RS $\left(29.3 \mathrm{~g}_{\text {plant }}{ }^{-1}\right)$. The lowest ST x RS interaction was $1.3 \mathrm{~g} \mathrm{plant}^{-1}$ in the $4^{\text {th }}$ sowing with $20 \mathrm{~cm}$ row spacing, while the highest value was $36.6 \mathrm{~g}$ with $40 \mathrm{~cm}$ row spacing in the first sowing. The lowest Y x ST x RS interaction was $0.010 \mathrm{~g} \mathrm{plant}^{-1}\left(2018 ; 4^{\text {th }} ; 20\right.$ and $\left.40 \mathrm{~cm}\right)$ and the highest value was $52.2 \mathrm{~g}$ plant $^{-1}\left(2018 ; 1^{\text {st }} ; 40 \mathrm{~cm}\right)$.

Afiah et al. (2018) analyzed 6 quinoa genotypes under the first and second crop conditions and found that the PW value ranged between 17.5 and $53.9 \mathrm{~g} \mathrm{plant}^{-1}$. On the other hand, Alandia et al. (2016) reported that different water regimes and different nitrogen applications led to changes in quinoa plant PW between 8.2 and $37.2 \mathrm{~g} \mathrm{plant}^{-1}$. While it was observed that the present study data were consistent with previous studies, it was suggested that the differences were due to the plant variety, and climate and cultural processes (Pulvento et al., 2010).

\section{The plant yield per parcel $\left(\mathrm{g} \mathrm{ha}^{-1}\right)$}

In the experiment, the analysis of the differences between the harvested plant samples based on PY demonstrated that the Y, ST, RS, Y x ST, Y x RS, ST x RS, Y x ST x RS interactions ( $\mathrm{p}<0.01)$ were statistically significant. The analysis of the PY variable based on the years revealed that PY was higher in 2018 (227.12 $\left.\mathrm{g} \mathrm{ha}^{-1}\right)$ when compared to 2017 (137.81 $\mathrm{g} \mathrm{ha}^{-1}$ ). The analysis of the applications based on ST, the highest value was observed in the first sowing (206.73 $\left.\mathrm{g} \mathrm{ha}^{-1}\right)$, and the lowest was obtained in the fourth sowing (152.02 $\mathrm{g} \mathrm{ha}^{-1}$ ). The analysis based on the RS application revealed that the lowest value was $163.64 \mathrm{~g} \mathrm{ha}^{-1}(20 \mathrm{~cm})$ and the highest value was obtained with $40 \mathrm{~cm}$ row spacing (204.80 $\left.\mathrm{g} \mathrm{ha}^{-1}\right)$.

The lowest Y x ST interaction was observed in the $4^{\text {th }}$ sowing in $2017\left(25.93 \mathrm{~g} \mathrm{ha}^{-1}\right)$ and the highest was observed in the fourth sowing in 2018 (278.12 $\left.\mathrm{g} \mathrm{ha}^{-1}\right)$. In Y x RS interaction, the lowest value was determined with $60 \mathrm{~cm} \mathrm{RS}\left(108.07 \mathrm{~g} \mathrm{ha}^{-1}\right)$ in 2017, and the highest value was observed with $\left.60 \mathrm{~cm} \mathrm{RS} \mathrm{(249.83} \mathrm{g} \mathrm{ha}^{-1}\right)$ in 2018. The ST x RS interaction data revealed that the lowest value was $132.09 \mathrm{~g} \mathrm{ha}^{-1}\left(4^{\text {th. }} ; 60 \mathrm{~cm}\right)$ and the highest value was $261.57 \mathrm{~g} \mathrm{ha}^{-1}\left(1^{\text {st }} ; 40 \mathrm{~cm}\right)$. The analysis based on Y x ST x RS interaction revealed that the lowest value was $7.12 \mathrm{~g} \mathrm{ha}^{-1}\left(2017 ; 4^{\text {th }} ; 60 \mathrm{~cm}\right)$ and the highest value was $319.91 \mathrm{~g} \mathrm{ha}^{-1}\left(2018 ; 4^{\text {th }} ; 20 \mathrm{~cm}\right)$.

Altuner et al. (2019) investigated the effects of 2 quinoa varieties and 3 sowing times and determined the plant yield between 15.4 and $29.2 \mathrm{~m}^{-2}$ and Maliro et al. (2017) analyzed 11 quinoa genotypes under different water regimes and determined that the plant yield varied between 0.2 and $9.9 \mathrm{~kg} \mathrm{da}^{-1}$. Based on these data, the present study findings were consistent with other studies.

\section{Harvest index (\%)}

The analysis of the differences between the HI data obtained with various applications in the study demonstrated that Y, ST, RS, Y x ST, Y x RS, ST x RS, Y x ST x RS 
interactions $(\mathrm{p}<0.01)$ were statistically significant. The analysis based on the years revealed that $\mathrm{HI}$ was higher in 2017 (31.7\%) when compared to 2018 (24.9\%). The analysis based on ST revealed that the highest value was obtained in the second sowing $(31.3 \%)$, and the lowest was obtained in the fourth sowing $(23.8 \%)$. The analysis based on the RS application showed that the lowest value was $23.2 \%(60 \mathrm{~cm} \mathrm{RS})$ and the highest value was obtained with $20 \mathrm{~cm}$ row spacing (30.9\%). On the other hand, HI value obtained with $40 \mathrm{~cm}$ row spacing was the second highest $(30.8 \%)$ and it was within the same group with $20 \mathrm{~cm}$ row spacing.

In Y x ST interaction, the lowest value was obtained in fourth sowing in 2018 (9.9\%), and the highest value was observed in fourth sowing in 2018 (37.6\%). In Y x RS interaction, the lowest value was determined with $60 \mathrm{~cm}$ row spacing in $2018(22.8 \%)$, and the highest was determined with $40 \mathrm{~cm}$ row spacing in 2017 (36.3\%). It was determined that the lowest value was $10.7 \%\left(4^{\text {th }} ; 60 \mathrm{~cm}\right)$ and the highest value was $36.8 \%$ $\left(2^{\text {nd }} ; 20 \mathrm{~cm}\right)$ based on the ST $x$ RS interaction data. Based on the Y x ST x RS interaction, the lowest value was $5.1 \%\left(2018 ; 4^{\text {th }} ; 60 \mathrm{~cm}\right)$ and the highest value was $52.5 \%\left(2017 ; 4^{\text {th }}\right.$; $40 \mathrm{~cm})$.

Eltahan et al. (2019) reported that HI varied between 16.4 and $46.6 \%$ in quinoa plants exposed to different salt stress in different row spacing applications, Onkur and Keskin (2019) reported that $\mathrm{HI}$ varied between 40.2 and $50.1 \%$ at different row spacing applications, Tan and Temel (2018) reported that HI varied between 5.6 and 38.0\% in 10 genotypes at two different locations. Reguera et al. (2018) analyzed 3 quinoa genotypes in 4 different locations and reported $\mathrm{HI}$ values between 40 and $50 \%$ and analyzed 6 quinoa varieties in the first and second growth seasons and reported that HI varied between 31.4 and $40.3 \%$. Geren and Gure (2017) reported that the HI value varied between 25.2 and $50.3 \%$ based on the administration of different nitrogen and phosphorus doses. Geren (2015) reported that the HI varied between 13.3-46.6 \% at different nitrogen levels applications.

\section{Conclusion}

In the present study conducted in Kahramanmaras province, where the Mediterranean climate prevails, winters are temperate and rainy, and summers are hot and dry, it was determined that the differences between the applications conducted with different sowing times and row spacing were significant. These results demonstrated that the cultivation of 'Q52' quinoa cultivar was adequate for Kahramanmaras region.

On the other hand, it was determined that quinoa sowing should be conducted in the first or second half of April based on the climate conditions, and the ideal row spacing is $40 \mathrm{~cm}$. While this spacing provides maximum benefits based on all investigated properties, it was suggested that the sowing time may vary since it could be effected by climatic factors more.

To improve the cultivation of quinoa, which is a novel crop in Turkey, it is very important to initially plan a good sowing calendar. The determination of the dates where the plant is exposed to the required temperatures, precipitation and relative humidity would increase the yield, which in turn would increase the interest in the cultivation of the plant.

Finally, agronomic guidelines should be developed for quinoa cultivation in Turkey and should be provided with adequate scientific knowledge for local communities, which would in turn will cultivate the crop nationwide. It was concluded that the varieties 
resistant to biotic and abiotic stress conditions that could be experienced regionally and nationwide should be determined, and further studies should be conducted on the development of new varieties.

\section{REFERENCES}

[1] Afiah, S. A., Hassan, W. A., Al Kady, A. M. A. (2018): Assessment of six quinoa (Chenopodium quinoa Willd.) genotypes for seed yield and its attributes under toshka conditions. - Zagazig Journal of Agricultural Research 45(6): 2281-2294.

[2] Alandia, G., Jacobsen, S. E., Kyvsgaard, N. C., Condori, B., Liu, F. (2016): Nitrogen sustains seed yield of quinoa under intermediate drought. - Journal of Agronomy and Crop Science 202(4): 281-291.

[3] Al-Naggar, A. M. M., Abd El-Salam, R. M., Badran, A. E. E., El-Moghazi, M. M. (2017): Genotype and drought effects on morphological, physiological and yield traits of quinoa (Chenopodium quinoa Willd.). - Asian Journal of Advances in Agricultural Research 3(1): $1-15$.

[4] Altuner, F., Oral, E., Kulaz, H. (2019): Impact of different sowing-times of the quinoa (Chenopodium quinoa willd.) and its varieties on the yield and yield components in TurkeyMardin ecology condition. - Applied Ecology and Environmental Research 17(4): 1010510117.

[5] Anonymous (2019): T.C. Ministry of forestry and water affairs, general directorate of meteorology, Kahramanmaras.

[6] Bazile, D., Jacobsen, S. E., Verniau, A. (2016): The global expansion of quinoa: Trends and limits. - Frontiers in Plant Science 7: 622.

[7] Dumanoglu, Z., Isik, D., Geren, H. (2016): Effect of different salt (NaCl) concentrations on the grain yield and some yield components of quinoa (Chenopodium quinoa Willd.). Journal of Agriculture Faculty of Ege University 53(2): 153-159.

[8] Eltahan, A., Kandil, E., Ibrahim, O., Wali, A. (2019): Saline water as supplementary irrigation and plant distance in relation to the productivity and quality of quinoa under calcareous soil conditions. - Journal of Sustainable Agricultural Sciences 45(3): 67-79.

[9] Geren, H., Kavut, Y. T., Topcu, G. D., Ekren, S., Istipliler, D. (2014): Effects of different sowing dates on the grain yield and some yield components of quinoa (Chenopodium quinoa Willd.) grown under Mediterranean climatic conditions. - Journal of Agriculture Faculty of Ege University 51(3): 297-305.

[10] Geren, H. (2015): Effects of different nitrogen levels on the grain yield and some yield components of quinoa (Chenopodium quinoa Willd.) under mediterranean climatic conditions. - Turkish Journal of Field Crops 20(1): 59-64.

[11] Geren, H., Kavut, Y. T., Altinbas, M. (2015): Effect of different row spacings on the grain yield and some yield characteristics of quinoa (Chenopodium quinoa Willd.) under Bornova ecological conditions. - Journal of Agriculture Faculty of Ege University 52(1): 69-78.

[12] Geren, H., Gure, E. (2017): A preliminary study on the effect of different N and P levels on the grain yield and other yield components of quinoa (Chenopodium quinoa Willd.). Journal of Agriculture Faculty of Ege University 54(1): 1-8.

[13] Hinojosa, L., González, J. A., Barrios-Masias, F. H., Fuentes, F., Murphy, K. M. (2018): Quinoa abiotic stress responses: A review. - Plants 7(4): 106.

[14] Hirich, A., Choukr-Allah, R., Jacobsen, S. E. (2014): Quinoa in Morocco - Effect of sowing dates on development and yield. - Journal of Agronomy and Crop Science 200: 371-377.

[15] Jacobsen, S. E. (2017): The scope for adaptation of quinoa in Northern Latitudes of Europe. - Journal of Agronomy and Crop Science 203(6): 603-613. 
[16] Kir, A. E., Temel, S. (2017): Determination of seed yield and some agronomical characteristics of different quinoa (Chenopodium quinoa Willd.) genotypes under irrigated conditions. - Igdir University Journal of the Institute of Science and Technology 7(1): 353361.

[17] Lesjak, J., Calderini, D. F. (2017): Increased night temperature negatively affects grain yield, biomass and grain number in Chilean quinoa. - Frontiers in Plant Science 8: 352.

[18] Long, N. V. (2016): Effects of salinity stress on growth and yield of quinoa. - Vietnam Journal of Agricultural Sciences 14(3): 321-27.

[19] Maliro, M. F., Guwela, V. F., Nyaika, J., Murphy, K. M. (2017): Preliminary studies of the performance of quinoa (Chenopodium quinoa Willd.) genotypes under irrigated and rainfed conditions of central Malawi. - Frontiers in Plant Science 8: 227.

[20] Naik, S., Paramesh, R., Siddaraju, R., Shankar, P. R. (2020): Studies on growth parameters in quinoa (Chenopodium quinoa Willd.). - International Journal of Chemical Studies 8(1): 393-397.

[21] Onkur, H., Keskin, B. (2019): The Effects of row spacing and intra-row spacing distance on seed yield and some plant properties of quinoa (Chenopodium quinoa Willd.). - KSU Journal of Agricultural and Nature 22(Suppl 1): 51-59.

[22] Prasad, P. V. V., Bheemanahalli, R., Jagadish, S. V. K. (2017): Field crops and the fear of heat stress-Opportunities, challenges and future directions. - Field Crops Research 200: 114-121.

[23] Pulvento, C., Riccardi, M., Lavini, A., d'Andria, R., Iafelice, G., Marconi, E. (2010): Field trial evaluation of two Chenopodium quinoa genotypes grown under rain-fed conditions in a typical Mediterranean environment in South Italy. - Journal of Agronomy \& Crop Science 196: 407-411.

[24] Ramesh, K., Devi, K. S., Gopinath, K. A., Devi, M. U. (2017): Physiological indices, yield and yield attributes of quinoa (Chenopodium quinoa Willd.) as influenced by dates of sowing and varied crop geometry. - International Journal of Current Microbiology and Applied Sciences 6(7): 1023-1034.

[25] Reguera, M., Conesa, C. M., Gil-Gómez, A., Haros, C. M., Pérez-Casas, M. Á., BrionesLabarca, V., Bolanos, L., Bonilla, I., Alvarez, R., Pinto, K., Mujica, Á., Bascunan-Godoy, L. (2018): The impact of different agroecological conditions on the nutritional composition of quinoa seeds. - PeerJ 6: e4442.

[26] Sangoi, L., Ender, M., Guidolin, A. F. (2000): Evolution of disease resistance of maize hybrids from different seasons in three plant populations. - Revista Ciência Rural, Santa Maria 30(1): 17-21.

[27] Scanlin, L., Lewis, K. A. (2017): Quinoa as a Sustainable Protein Source: Production, Nutrition, and Processing. - Sustainable Protein Sources: 223-238.

[28] Tan, M., Temel, S. (2017): Studies on the adaptation of quinoa (Chenopodium quinoa Willd.) to Eastern Anatolia Region of Turkey. - In: AGROFOR International Journal 2(2).

[29] Tan, M., Temel, S. (2018): Performance of some quinoa (Chenopodium quinoa Willd.) genotypes grown in different climate conditions. - Turkish Journal of Field Crops 23(2): 180-186.

[30] Wahid, A., Gelani, S., Ashraf, M., Foolad, M. R. (2007): Heat tolerance in plants: an overview. - Environmental and Experimental Botany 61(3): 199-223.

[31] Wu, G., Peterson, A. J., Morris, C. F., Murphy, K. M. (2016): Quinoa seed quality response to sodium chloride and sodium sulfate salinity. - Frontiers in Plant Science 7: 790.

[32] Wu, G., Ross, C. F., Morris, C. F., Murphy, K. M. (2017): Lexicon development, consumer acceptance, and drivers of liking of quinoa varieties. - Journal of Food Science 82: 9931005 . 